\title{
GLYCOPEPTIDES SUSCEPTIBILITY AMONG ENTEROCOCCI ISOLATED FROM A POULTRY FARM IN SÃO PAULO, BRAZIL (1996/1997)
}

\author{
Ivani Lúcia Leme ${ }^{1 *}$; Antonio José Piantino Ferreira²; José Américo Bottino²; Antonio Carlos C. Pignatari ${ }^{1}$ \\ ${ }^{1}$ Disciplina de Doenças Infecciosas e Parasitárias, Universidade Federal de São Paulo, São Paulo, SP, Brasil. ${ }^{2}$ Departamento de \\ Patologia, Faculdade de Medicina Veterinária e Zootecnia, Universidade de São Paulo, São Paulo, SP, Brasil
}

Submitted: August 13, 1999; Returned to authors for corrections: December 16, 1999; Approved: January 11, 2000

\begin{abstract}
Enterococci resistance to glycopeptides was evaluated em Brazilian poultry fed with feed supplemented with avoparcin as growth promoter. The susceptibility to the glycopeptides avoparcin, teicoplanin and vancomycin was determined for 217 enterococci isolated from cloacal swabs (one swab per bird) in tests and controls groups. Tests group comprised three groups (A, B and C) of Hubbard broiler-chickens 14, 21 and 35 days old, respectively. These birds were from one single farm, with a common feed source supplemented with avoparcin $(10 \mathrm{mg} / \mathrm{kg}$ of feed). Controls groups (1 and 2) comprised 25 and 42 days old broilers, respectively, obtained from the Faculty of Veterinary Medicine's aviary (University of São Paulo) where avoparcin was never used. No glycopeptide resistant enterococci strain was found, but an increase of Enterococcus faecium in faeces of chickens fed with avoparcin, independent of the age of the bird, was detected.
\end{abstract}

Key words: glycopeptides, avoparcin, vancomycin, resistance, Enterococcus

\section{INTRODUCTION}

Enterococci are receiving increased attention because their role in serious human hospital infections $(20,26)$. Reports from Europe about vancomycin-resistant enterococci (VRE) correlate this resistance with the use of the vancomycin-like glycopeptide avoparcin as growth promoter in the feed for poultry and pigs.

The extralabel uses of antibiotics in food-producing animals can increase the level of drug-resistant zoonotic pathogens in treated animals $(3,5,6,7,11,12,14,17,32)$. Antimicrobial resistant enterococci can be transmitted to humans through contact with farm animals and through the environment $(1,12$, 26). There are reports from Europe on occupationally acquired vancomycin resistant Enterococcus faecalis infection from poultry fed with feed supplemented with avoparcin $(1,2,4,9$, $10,22,24)$.

Once no data is available about vancomycin resistant enterococci strains in Brazilian poultry farms we evaluated the susceptiblity of enterococci isolated from broilers chickens to the glycopeptides avoparcin, teicoplanin and vancomycin.

The objective of this study was to investigate the presence of VRE in a São Paulo poultry farm.

\section{MATERIALS AND METHODS}

\section{Faecal samples}

In 1996-1997 period, cloacal swab samples were collected from Hubbard broiler-chickens fed with feed suplemented or not with avoparcin. One cloacal swab was obtained from each bird, in both test and control groups. Test groups were obtained in a poultry farm near to São Paulo city, Brazil. This farm has several aviaries, each one with birds in a different stage of growth. The criteria for inclusion of this farm in the study was the introduction of feed containing avoparcin. Test groups A, B and $\mathrm{C}$ comprised aviaries with 14, 21 and 35 days old birds, respectivelly. Each aviary had 5,000 to 8,000 birds and the chickens were selected aleatorily. The birds of test groups received feed supplemented with avoparcin from the first day

\footnotetext{
* Corresponding Author. Mailing address: Rua Napoleão de Barros, 690 - 2º andar, Vila Clementino, CEP 04024-002, São Paulo, SP, Brasil. Fax +55 11 $571-8935$.

E-mail: illeme.dmed@epm.br
} 
until the $35^{\text {th }}$ day of life $(10 \mathrm{mg} / \mathrm{kg}$ feed). The control groups were obtained at the aviary of the Faculty of Veterinary Medicine, University of São Paulo, where avoparcin was never used. The birds from Control groups 1 and 2 were 25 and 42 days old, respectivelly. It was not possible to obtain a 14 days old control group. Details and characteristics of the sources and enterococci isolated in each source are shown in Tables 1 and 2.

\section{Microbiology}

Each faecal sample was inoculated into a tube with $0.7 \%$ nutrient agar (Nutrient agar, Difco, Detroit, MI, USA). Samples were transported to the microbiology laboratory of the Faculty of Veterinary Medicine, University of São Paulo, and, within 24h, direct plated onto blood-agar plates (Columbia Blood Agar, Difco, Detroit, Mi, USA) and onto blood agar plates supplemented with $5 \%$ sheep blood and $300 \mathrm{U} / \mathrm{ml}$ of polimixin B (Roerig-Pfizer, manufactured by The Upjohn Company, Kalamazoo, Michigan, USA) $(23,25)$.

Pure cultures were submitted to Gram stain, catalase, $6.5 \%$ $\mathrm{NaCl}$ and bile-aesculin tests $(13,15,16)$. The partially identified strains were frozen in $10 \%$ skim milk at $-20^{\circ} \mathrm{C}$ for further species identification. Three or four colonies from each suspicious sample, identified as Enterococcus sp, were selected for identification at the species level by Facklam and Sahm method (16): tolerance to bile, growth in $6.5 \%$ salt, fermentation of pyruvate, pigment production, haemolysis in sheep blood agar, carbohydrates fermentation (mannitol, sorbitol, sorbose, arabinose, raffinose and sucrose), arginin hydrolysis, $0.04 \%$ telurite tolerance and motility. Cultures were monitored for yellow pigmentation on cotton swabs used to pick up growth from BHI plates incubated overnight. Haemolysis (alpha, beta, non-haemolysis) was determined by observation of 24-h growth on a blood-agar plate (Columbia Blood Agar 5\% sheep blood Difco). Inoculum preparation for the conventional tests of identification was done on blood-agar plates.

\section{Susceptibility tests}

A screening method was performed to detect vancomycin resistance by an agar-dilution method in brain-heart infusion agar (BHIA, Oxoid, Basingstoke, Hampshire, England) with 6 $\mu \mathrm{g} / \mathrm{ml}$ of vancomycin according to National Committee for Clinical Laboratory Standards (NCCLS) $(29,30)$.

Minimum inhibitory concentrations (MIC) of vancomicin hydrochloride (Europharma, Korea), teicoplanin (Lepetit, Italy), and avoparcin sulphate analytical standard (Roche, England) were determined using the standard agar dilution method, according to NCCLS $(29,30,32)$. Miller Hinton Agar (Oxoid, Basingstoke, Hampshire, England), spot inoculated with approximately $10^{4} \mathrm{CFU}$, was used.

For quality-control tests, vancomycin-susceptible Enterococcus faecalis ATCC 29212 and vancomycin-resistant ATCC 51299 (VanB phenotype) were used (31).

\section{RESULTS}

A total of 217 isolates was obtained from 165 samples (Tables 1 and 2). The MIC results for avoparcin, teicoplanin and vancomycin in both Test and Control groups are shown in Table 3. No isolate presented glicopeptide resistance.

The impact of avoparcin on the microbiota of birds of test and control groups, according to the age, was compared. A prevalence of $E$. faecium in the test groups, independent of the age of bird, was detected (Table 2). E. faecium was detected in $52.8 \%$ of birds of the Test groups, but only in $11.9 \%$ of the control groups.

\section{DISCUSSION}

By December 1995, there were no publications or reports on vancomycin resistant enterococcci in Brazil, on both veterinary or clinical areas. The first vancomycin-resistant enterococci (E. faecium) with vanA phenotype was isolated in 1997 in a Brazilian human hospital $(33,34)$.

In spite of the prohibition of extralabel use of avoparcin in the USA and various European countries, its use as feed additive was unrestricted in Brazil until 1998, when the extralabel use of avoparcin was also prohibited.

Enterococci are part of the gut microbiota in both humans and birds. The veterinary use of avoparcin may therefore provide a selective pressure for the emergence of glycopeptide resistance in enterococci colonized farm animals. The avoparcin selective pressure was withdrawn from the Brazilian agriculture in 1998, but the use of glicopeptides vancomycin and teicoplanin is continuous in hospitals.

With respect to the frequent use of vancomicin in hospitals, similar situation occurs in Brazil and in USA $(11,27,28)$. However, in Brazil avoparcin is used in production farms. Frieden et al. suggested that the glycopeptide-resistance in enterococci was originated in hospitals, by inapropriate use, and then spread to the comunity (18).

In spite of the isolation of glycopeptides non-resistant enterococci (Table 3), important alterations in the cloacal microbiota of poultry fed with feed supplemented with avoparcin were detected. E. faecium was the major organism isolated in this group, in contrast with the control group, where another enterococci species, less pathogenic, prevailled. The use of avoparcin may be the cause, selecting the microbiota. All growth promoters have similar mecanisms of action, and select the most adapted organisms in the microbiota. It was reported that benzylpenicillin in feed as growth promoter also selects E. faecium (19).

The bacteria selected by the antibiotic present in the feed is independent of the type of growth promoter used, but depends on the nature of the microbiota exposed to the antibiotic. Barrow showed that the use of avoparcin can reduce viable counts of 
Table 1. Sources of enterococci isolated from faeces of chicken

\begin{tabular}{lcc}
\hline Group & Number of birds & $\begin{array}{c}\text { Enterococcus sp. isolated* } \\
\mathrm{n}\end{array}$ \\
\hline Birds fed with feed with avoparcin: & & 38 \\
Test A (chicken living with 14-days-old) & 33 & 49 \\
Test B (chicken living with 21-days-old) & 30 & 38 \\
Test C (chicken with 35-days-old) & 37 & 125 \\
Total Test group (A, B and C) & 100 & \\
Birds fed with feed without avoparcin: & & 43 \\
Control 1 (chicken living with 42-days-old) & 30 & 49 \\
Control 2 (chicken living with 25-days-old) & 35 & 92 \\
Total Control Group (1 and 2) & 65 & 217 \\
\hline TOTAL & 65 & 2 \\
\hline
\end{tabular}

* cloacal swab

Table 2. Enterococcus species isolated from Control and Test chicken groups

\begin{tabular}{|c|c|c|c|c|c|c|c|c|c|}
\hline & \multicolumn{4}{|c|}{$\begin{array}{l}\text { CONTROL GROUPS } \\
\text { Feed without avoparcin } \\
\qquad N=65 \text { birds }\end{array}$} & \multicolumn{5}{|c|}{$\begin{array}{c}\text { TEST GROUPS } \\
\text { Feed without avoparcin } \\
\mathrm{N}=100 \text { birds }\end{array}$} \\
\hline & $\begin{array}{c}\text { Control } 1 \\
\mathrm{~N}=30 \text { birds } \\
(42 \text {-days-old })\end{array}$ & $\begin{array}{c}\text { Control } 2 \\
\mathrm{~N}=35 \text { birds } \\
\text { (25-days-old) } \\
\end{array}$ & & & $\begin{array}{c}\mathrm{A} \\
\mathrm{N}=33 \text { birds } \\
\text { (14-days-old) }\end{array}$ & $\begin{array}{c}\mathrm{B} \\
\mathrm{N}=30 \text { birds } \\
\text { (21-days-old) }\end{array}$ & $\begin{array}{c}\mathrm{C} \\
\mathrm{N}=37 \text { birds } \\
\text { (35-days-old) }\end{array}$ & & tal \\
\hline Species* & & & $\mathrm{n}$ & $\%$ & & & & $\mathrm{n}$ & $\%$ \\
\hline E. casseliflavus & 27 & 11 & 38 & 41.4 & 3 & 1 & 8 & 12 & 9.6 \\
\hline E. dispar & 0 & 1 & 1 & 1.1 & 01 & 0 & 0 & 1 & 0.8 \\
\hline E. durans & 1 & 2 & 3 & 3.2 & 2 & 5 & 0 & 7 & 5.6 \\
\hline E. faecalis & 6 & 23 & 29 & 31.5 & 3 & 5 & 0 & 8 & 6.4 \\
\hline E. faecium & 6 & 5 & 11 & 11.9 & 21 & 27 & 18 & 66 & 52.8 \\
\hline E. gallinarum & 8 & 1 & 9 & 9.8 & 3 & 0 & 6 & 9 & 7.2 \\
\hline E. hirae & 1 & 0 & 1 & 1.1 & 2 & 0 & 3 & 5 & 4.0 \\
\hline E. mundtii & 0 & 0 & 0 & 0 & 2 & 0 & 3 & 5 & 4.0 \\
\hline E. raffinosus & 0 & 0 & 0 & 0 & 1 & 11 & 0 & 12 & 9.6 \\
\hline Total & 49 & 43 & 92 & 100 & 38 & 49 & 38 & 125 & 100 \\
\hline
\end{tabular}

intestinal enterococci and Gram-negative anaerobic bacteria and an increase of Salmonella typhimurium and E. coli, confirming the antibiotic activity of avoparcin in the alimentary tract of chickens innoculated orally with a nalidixic acid-resistant $S$. typhimurium (8).

Differences in the proportion of each species, among enterococci in both control and test groups, were expected. Kaukas et al. (21) showed that the patterns of fecal microbiota change with poultry age and can be modified in birds treated with tylosin or ampicillin.

In view of the increasing nosocomial significance of Enterococcus faecium and E. faecalis and the alarming incidence of these oportunistic microorganisms in the Brazilian medical centers since 1997 (34), this study can contribute to elucidate some aspects of VRE epidemiology. Based in our results, the ecological impact of the use of avoparcin in farms can be better evaluated. A continuous surveillance program of glycopeptides resistant enterococci in animals and feed in Brazil is recommended, as well as the use of other antibiotics in the veterinary area.

\section{ACKNOWLEDGMENTS}

The gift of the antimicrobial drugs is appreciated. 
Table 3. Susceptibility to glycopeptides of enterococci isolated from faeces of chickens fed supplemented with ou without avoparcin

\begin{tabular}{|c|c|c|c|c|c|c|c|}
\hline \multirow[t]{2}{*}{ Group } & \multirow{2}{*}{$\begin{array}{c}\text { Number of } \\
\text { Enterococcus sp } \\
\text { tested } \\
\mathrm{n}\end{array}$} & \multicolumn{2}{|c|}{$\begin{array}{l}\text { Vancomycin* } \\
\text { MIC Breakpoint } \\
\geq 32 \mu \mathrm{g} / \mathrm{ml} \\
\end{array}$} & \multicolumn{2}{|c|}{$\begin{array}{c}\text { Teicoplanin* } \\
\text { MIC Breakpoint } \\
\geq 32 \mu \mathrm{g} / \mathrm{ml} \\
\end{array}$} & \multicolumn{2}{|c|}{$\begin{array}{c}\text { Avoparcin** } \\
\text { MIC Breakpoint } \\
=8 \mu \mathrm{g} / \mathrm{ml}\end{array}$} \\
\hline & & $\begin{array}{l}\mathrm{MIC}_{50} \\
\mu \mathrm{g} / \mathrm{ml} \\
\end{array}$ & $\begin{array}{l}\mathrm{MIC}_{90} \\
\mu \mathrm{g} / \mathrm{ml} \\
\end{array}$ & $\begin{array}{l}\mathrm{MIC}_{50} \\
\mu \mathrm{g} / \mathrm{ml} \\
\end{array}$ & $\begin{array}{l}\mathrm{MIC}_{90} \\
\mu \mathrm{g} / \mathrm{ml} \\
\end{array}$ & $\begin{array}{l}\mathrm{MIC}_{50} \\
\mu \mathrm{g} / \mathrm{ml}\end{array}$ & $\begin{array}{l}\mathrm{MIC}_{90} \\
\mu \mathrm{g} / \mathrm{ml} \\
\end{array}$ \\
\hline \multicolumn{8}{|c|}{ Feed with avoparcin } \\
\hline Test Group A & 38 & 1 & 4 & 1 & 1 & 1 & 4 \\
\hline Test Group B & 49 & 1 & 4 & 1 & 1 & 1 & 4 \\
\hline Test Group C & 38 & 4 & 4 & 1 & 1 & 2 & 4 \\
\hline \multicolumn{8}{|c|}{ Feed withouth avoparcin } \\
\hline Control Group 1 & 43 & 1 & 4 & 1 & 1 & 1 & 1 \\
\hline Control Group 2 & 49 & 2 & 2 & 1 & 1 & 4 & 4 \\
\hline TOTAL $(\mathrm{N})$ & 217 & & & & & & \\
\hline
\end{tabular}

* NCCLS (REF. 29, 30); ** Bager, DANMAP food (REF. 3); MIC, minimal inibitory concentration

MIC range found in the differents groups of enterococci:

Control Groups 1 and 2: vancomycin, $1-4 \mu \mathrm{g} / \mathrm{ml}$; teicoplanin, $1 \mu \mathrm{g} / \mathrm{ml}$; avoparcin, $1-4 \mu \mathrm{g} / \mathrm{ml}$

Test Groups A:vancomycin, $1-8 \mu \mathrm{g} / \mathrm{ml}$; teicoplanin, $1-4 \mu \mathrm{g} / \mathrm{ml}$; avoparcin, $1-4 \mu \mathrm{g} / \mathrm{ml}$

Test Groups B:vancomycin, $1-8 \mu \mathrm{g} / \mathrm{ml}$; teicoplanin, $1 \mu \mathrm{g} / \mathrm{ml}$; avoparcin, $1-4 \mu \mathrm{g} / \mathrm{ml}$

Test Groups C:vancomycin, $1-4 \mu \mathrm{g} / \mathrm{ml}$; teicoplanin, $1 \mu \mathrm{g} / \mathrm{ml}$; avoparcin, $1-4 \mu \mathrm{g} / \mathrm{ml}$

\section{REFERENCES}

\section{RESUMO}

\section{Perfil de suscetibilidade a glicopeptídeos em enterococos isolados de frangos de um aviario de São Paulo, Brasil}

(1996-1997)

Para avaliar a resistência de enterococos de origem animal aos antibióticos glicopeptídeos foi projetado um estudo em aves comerciais que usavam rações suplementadas com avoparcina como promotor de crescimento. A suscetibilidade aos glicopeptídeos avoparcina, teicoplanina e vancomicina foi determinada em 217 enterococos isolados de fezes de frango colhidas através de swab cloacal (uma amostra/ave). Nos três grupos Teste foram usadas fezes de frangos em diferentes fases de crescimento, com 14, 21 e 35 dias de idade. As aves foram alimentadas com ração contendo avoparcina $(10 \mathrm{mg} / \mathrm{kg}$ de ração) desde o primeiro dia de vida. Como controle foram usadas fezes de frangos do biotério da Faculdade de Medicina Veterinária da Universidade de São Paulo, onde nunca foram usados glicopeptídeos nas rações das aves ou no local. Nenhum enterococo resistente à vancomicina (ERV) foi isolado nas amostras examinadas, porém, foi detectado um aumento de Enterococcus faecium na microbiota fecal de frangos que utilizavam avoparcina na ração, independente da idade da ave. Palavras-chave: glicopeptídeos, avoparcina, vancomicina, frangos, resistência a drogas, Enterococcus.
1. Aarestrup, F. M.; Ahrens, P.; Madsen, M.; Pallesen, L.; Poulsen, L. and Westh, H. Glycopeptide susceptibility among danish Enterococcus faecium and Enterococcus faecalis isolates of animal and human origin and PCR identification of genes within the VanA cluster. Antimicrob. Agents Chemother, 40(8):1938-1949, 1996.

2. Aarestrup, F.M. Ocurrence of glycopeptide resistance among Enterococcus faecium isolates from conventional and ecological poultry farms. Microb. Drug Resist., 1:255-7, 1995.

3. Bager F.; Madsen M.; Christensen J. and Aarestrup F. M. Avoparcin used as a growth promoter is associated with the occurence of vancomycinresistant Enterococcus faecium on Danish poultry and pig farms. Prev. Vet. Med., 31(1-2):95-112, 1997.

4. Baptista, M.; Departieu, F.; Courvalin, P. and Arthur, M. Specificity of Induction of Glycopeptide Resistance Genes in Enterococcus faecalis. Antimicrob Agents Chemoter, 40(10):2291-2295, 1996.

5. Bates, J. Epidemiology of vancomycin-resistant enterococci in the community and the relevance of farm animals to human infection. J. Hosp. Infect., 37(2):89-101, 1997.

6. Bates, J.; Jordens, J. Z. and Griffiths, D. T. Farm animals as a putative reservoir for vancomycin-resistant enterococcal. J. Antimicrob. Chemother, 34:507-516, 1994

7. Bates, J.; Jordens, Z. and Selkon, J.B. Evidence for animal origin of vancomycin-resistant enterococci. Lancet, 342:490-491, 1993.

8. Barrow, P. Further observations on the effect of feeding diets containing Avoparcin on the excretion of salmonellas by experimentally infected chickens. Epidem. Inf., 102, 239-252, 1989.

9. Bogaard A.E.; London, N.; Driessen, C. and Stobberingh, E. Vancomycinresistant enterococci in turkeys and farmers. N Engl J Med., 337(21):15581559, 1997.

10. Chenoweth, C.and Schaberg, D. The epidemiology of enterococci. Eur. J. Clin. Microbiol. Infect. Dis., 9:80-89, 1990.

11. Cormican, M. G.; Erwin, M. and Jones, R. Avoparcin, a glycopeptide used in animal foods:antimicrobial spectrum and potency tested against human isolates from the United States. Diagn. Microbiol. Infect. Dis., 29:241-248, 1997. 
12. Das, I.; Fraise, A.and Wise, R. Are glycopeptide-resistant enterococci in animal a threat to human beings? Lancet, 349:9057, 1997.

13. Devriese, L. A.; Bruno, P; Van Damme, L.; Kersters, K. and Haesebrouck, F. Identification of Enterococcus species isolated from foods of animal origin. Int. J. Food Microbiol., 26:187-197, 1995.

14. Donnely, J. P.; Voss, A.; Witte, W. and Murray, B.E. Reply to: Does the use in animals of antimicrobial agents, including glycopeptide antibiotics, influence the efficacy of antimicrobial therapy in humans? [letter] $J$. Antimicrob. Chemother, 37:390-392, 1996.

15. Facklam, R. and Collins, M.DIdentification of Enterococcus species isolated from humam infections by a conventional test scheme. J. Clin. Microbiol., 27:731-4, 1989.

16. Facklam, R. and Sahm, D.A. Enterococcus. In: A. Ballows (editor), Manual of Clinical Microbiology. American Society for Microbiology, Washington, DC, 1995, p. 308-314.

17. Felmingham, D.; Brown, D.F. and Soussy, C.J. European Glycopeptide Susceptibility survey of Gram-positive bacteria for 1995. European Glycopeptide Resistance Survey Study Group. Diag. Microbiol. Infect. Dis., 31(4):563-71, 1998.

18. Frieden, T. R., S. S. Munsiff, D. E.Low, B. M. Willey, G. Williams, Y. Faur, W. Eisner, S. Warren, and B. Kreiswirth. Emergence of vancomycinresistant enterococci in New York city. Lancet, 342:76-79, 1993.

19. Jeffries, L.; Coleman, K. and Bunyan, J. Antimicrobial substances and chick growth promotion: comparative studies on selectd compounds in vitro and in vivo. Br. Poult. Sci., 18:295-308, 1977.

20. Jordens, J. Z.; Bates, J. and Griffiths, D. Faecal carriage and nosocomial spread of vancomycin-resistant Enterococcus faecium. J. Antimicrob. Chemother, 34:515-528, 1994.

21. Kaukas, A.; Hinton, M. and Linton, A. H. The effect of ampicillin and tylosin on the faecal enterococci of healthy young chickens. J. Appl. Bacteriol., 62:441-7, 1987

22. Klare, I.; Heier, H.; Claus, H.; Reissbrodt, R and Witte, W. vanA-mediated high-level glycopeptide in Enterococcus faecium from animal husbandry. FEMS Microbiol. Letter, 125:165-172, 1995.

23. Knudtson, L. M.; Hartman, P. Routine procedures for isolation nad identification of enterococci and fecal streptococci. Appl. Environ. Microbiol., 58(9) 3027-3031, 1992.

24. Kruse, H. and Rorvik, L. M. The use of avoparcin as a growth promoter and the ocorrence of vancomycin resistant Enterococcus spp. in poultry production [abstract] In: Program and Abstracts of the 96th General Meeting of the American society for Microbiology, New Orleans. American Society for Microbiology; Washington DC, 1996, p 36.
25. Landman, D.; Quale, J.M.; Oydna, E.; Willey, V.; Ditore, M.; Zaman, M.; Patel, K.; Saurina, G. and Huang, W. Comparison of five selective media for identifying fecal carriage of vancomycin-resistant enterococci. J. Clin. Microbiol., 34(3):751-752, 1996.

26. McDonald, L.C.; Kuechnert, J.; Tenover, F. C.; Jarvis, W. VancomycinResistant Enterococci Outside the Health-Care Setting: Prevalence, sources, and Public Health Implications. Emerging Infectious Diseases EID V3N3, Center for Disease Control and Prevention, Atlanta, Georgia, 1997.

27. Murray, B.E. Editorial Response: What Can We Do About VancomycinResistant Enterococci? Clin. Infect. Dis., 20:1134-6, 1995.

28. Murray, B.E. The life and times of the Enterococcus. Clin. Microbiol. Rev., 3:46-65; 1990.

29. National Committee For Clinical Laboratory Standards (NCCLS. Approved standard M7-A3: methods for dilution antimicrobial susceptibility tests for bacteria that grow aerobically. 3th ed. Villanova, PA, 1993a.

30. National Committee For Clinical Laboratory Standards (NCCLS) Approved standard M2-A5: methods for dilution antimicrobial susceptibility tests for bacteria that grow aerobically. 5th ed. Villanova, PA, 1993b.

31. Swenson, J.M. Molecular characterization and multilaboratory evaluation of Enterococcus faecalis ATCC 51299 for quality control of screening tests for vancomycin and high-level aminoglycoside resistance in enterococci. J. Clin. Microbiol., 33: 3019-3021, 1995.

32. Thal, L.; Chow, J. W.; Mahayni, R.; Bonilla, H.; Perri, M. B.; Donabedian, S.; Silverman, J.; Taber, S.and Zervos, M. Characterization of Antimicrobial Resistance in Enterococci of Animal Origin. Antimicrob. Agents Chemother., 39(9):2112-2115, 1995.

33. Vilins, M.; Valdetaro, F.; Blecher, S.; Pignatari, A.C.; Medeiros, E. A.; Zanella, R.C.; Brandileone, M.C.C.; Nascimento, A. B. G. and Salomão, R. Prevalência de Enterococcus resistente à vancomicina (VRE) em hospital de grande porte na região metropolitana de São Paulo. VI Congresso Brasileiro de Controle de Infecção e Epidemiologia Hospitalar, Campos de Jordão, São Paulo, Brazil. Abstract 02 - Microbiologia, 1998, p. 203.

34. Zanella, R.C.; Valdetaro, F.; Lovgren, M.; Tyrrel, G.; Bokermann, S.; Almeida, s.; Vieira, v.; Brandileone, M.C. First confirmed case of a Vancomycin-resistant enterococcus faecium with vanA phenotipe from Brazil: Isolation from a meningitis case in São Paulo. Microb. Drug Resistance, 5(2), 159-162, 1999. 